\title{
First report of garlic virus D in garlic from D.R. Congo
}

\author{
Shahana Majumder ${ }^{1} \cdot$ Kate Mbay $^{1} \cdot$ Jyoti Singh $^{1}$ \\ Published online: 19 March 2018 \\ (C) Società Italiana di Patologia Vegetale (S.I.Pa.V.) 2018
}

Several viruses belonging to the genera Potyvirus, Carlavirus, and Allexivirus are known to infect garlic and lower their yield worldwide (Van Dijk 1994; Walkey and Antill 1989). This study was undertaken to investigate the status of viral infection in Congolese garlic. Ten garlic bulbs were collected in June of 2017 from fields in the Buzito, Katemba and Kiringa regions of Congo. Samples were tested for the presence of allexiviruses by reverse transcription (RT)-PCR. Total RNA was extracted from $100 \mathrm{mg}$ of leaves using an RNeasy Plant Minikit (Qiagen) according to the manufacturer's protocol and RT-PCR was performed using primers designed in conserved regions at the $3^{\prime}$-end of open reading frame 6 and the $3^{\prime}$ end of the non coding region of allexivirus sequences (Dovas et al. 2001). Expected amplicons of approximately $200 \mathrm{bp}$ were obtained from all the samples tested. Direct sequencing of the PCR products from three samples produced ca. 159-
$160 \mathrm{bp}$ long nucleotide sequences showing $92 \%$ to $94 \%$ identity with garlic virus D (GVD) from the United Kingdom (GenBank accession no. L38892.1) and Argentina (KR819505.1), respectively. To our knowledge, this is the first report of garlic virus D in garlic from D.R. Congo.

\section{References}

Dovas CI, Hatziloukas E, Solomon R, Barg E, Shiboleth Y, Katis NI (2001) Comparison of methods for virus detection in Allium spp. J Phytopathol 149:731-737

Van Dijk P (1994) Virus diseases of Allium species and prospects for their control. Acta Hortic (358):299-306

Walkey DGA, Antill DN (1989) Agronomic evaluation of virus-free and virus infectedgarlic(Allium sativum L.) J Hortic Sci 64:53-60
Shahana Majumder

shahanamajumder@gmail.com

1 Department of Biotechnology, Sharda University, Knowledge Park III, G. Noida 201306, India 